\title{
SOME PRAXIOLOGICAL REFLECTIONS ON THE RELIABILITY OF POLITICAL FORECASTING
}

Keywords: praxiology, reliability, political forecasting, Stratfor.

ABSTRACT: The aim of this paper is to present some praxiological reflections and doubts concerning the nature and reliability of political forecasting in present times.

\section{INTRODUCTORY REMARKS}

Some researchers try to predict the future of individual states, groups of states or the global political construction (Huntington 1996; Lubowski 2013; Morris 2010; Brzeziński 2013; Buchanan 2011; Murray 2017; Lorenzi, Berrebi 2011; Brunet, Guichard 2011; Kołodko 2018; De Mesquita, 2002, 2009, 2011; Franklin, 2012; Fukuyama, 2006; Gleiber, 2006; Mauldin, 2005; McRae, 1996; Randers, 2012; Slonim, 2018).

In this paper I would like to present some remarks concerning the political forecasts published by G. Friedman and Stratfor (Friedman, 2009, 2011).

1 Benon Zbigniew Szałek, Professor Ordinarius, University of Szczecin, Faculty of Humanities, Institute of Political Science and European Studies, Chair of Praxiology, Heuristics and Political Marketing. ORCID ID: 0000-0002-9692-0885 


\section{THE FORECASTS PUBLISHED BY G. FRIEDMAN AND STRATFOR}

The North American think tank Stratfor (an abbreviation of: 'Strategic Forecasting'; a 'private global intelligence company, called 'shadow CIA', headed by G. Friedman (Dungaciu et al. 2018)) published in the years 1995-2015 a series of overlapping 'Decade Forecasts' (1995-2005, 2000-2010, 2005-2015, 20102020, 2015-2025).

This short paper is not intended to analyse the content of these 'Forecasts' in a detailed way - it is meant to become a point of departure for a new approach to the problem of political forecasting.

I will focus my attention on 3 basic Decade Forecasts (1995-2005, 2005$2015,2015-2025)$ - my intention is to illustrate the problem with examples of obvious shortcomings.

In the forecast for the years 1995-2005 one can read that in China: 'we expect growing instability, including the strong possibility of fragmentation and civil war, between the interior and coastal regions' and: 'as we expect, China will disintegrate in the early part of the 1995-2005 decade' (Decade..., 1995, p.4-5). As we know - this never happened.

In particular, Dungaciu et al. stress that: 'As we all know, China does not only fail to disintegrate in the 1995-2005 decade, but actually shows significant economic growth' (Dungaciu et al., 2018, p. 171).

There is not a word on the economic and military cooperation between Russia and China (the Shanghai Cooperation Organization, 2001; in 2017 joined by India and Pakistan).

According to Dungaciu et al., the forecast for the years 1995-2005 'misses the main subject of the following 15 years: international terrorism and Islamic fundamentalism' (Dungaciu et al., 2018,p.170). This forecast does not mention an event comparable to 9/11. 2001 and its consequences (Dungaciu et al. accept the official version of the WTC case). On the contrary, the forecast excludes the possibility of a systemic convulsive war like the Napoleon Wars. In particular: 'While political suasion might be used, military intervention will become more and more rare during this coming decade. Moreover: 'The United States will ... avoid engagement on the mainland beyond attempting to maintain the balance of power through political and economic means' (Decade 1995-2005..., p.3-5). 
Let us recall here the intervention in Afghanistan and Iraq - instead of a 'blue water' strategy.

In a later Decade Forecast (for the years 2015-2025) Stratfor admits that: 'We didn't anticipate 9/11, and more important, we did not anticipate the scope of the American response"(Decade 2015-2025..., 2015, p.1).

According to the Forecast, the decade 1995-2005 'will be seen as a golden age' (Decade 1995-2005..., 1995, p.2). However, what about the huge U.S. deficit with East Asia and the external debt exceeding 10 trillion USD?

As for the position of the U.S in the world, Stratfor optimistically stated: 'Today, no simple power threatens hegemony (of the U.S. - B.Z.Sz.)' (Decade 1995-2005..., 1995, p.4). This opinion illustrates the problem of methodological shortcomings: general systems theory requires taking into consideration not only systems but also their environment/surroundings. In particular, the U.S. may have very serious problems with natural environment.

In spite of these shortcomings, Stratfor (headed by G. Friedman) declares: 'We were quite pleased with our first forecast's accuracy'. Stratfor tries to explain the shortcomings in the following way: 'A decade forecast.,.. is about predicting the unexpected... Predicting in 1995 that United States would invade Afghanistan in 2001 would have been enormously difficult' (Decade 2015-2025..., 2015, p.1).

Let us deal with the Decade Forecast: 2005-2015.

Some predictions are interesting. On the one hand, according to Stratfor: 'we don't expect to see a major, long-term economic contraction or period of stagnation' (Decade 2005-2015..., 2005, p.4). It is obvious that something like that happened in the years 2008-2013. On the other hand, we find in the Forecast (p.32) an intriguing opinion: 'let us say the EU suffers a massive recession. Then, either simultaneously or a few years later, Russia decides to reintegrate Ukraine....and position nuclear weapons near its border with Europe' (Decade 2005-2015..., 2005, p.32). Moreover, in 2005 Stratfor predicted that Russia will reclaim its former territories, 'beginning with the Baltics, and Georgia... if not by 2010 then by 2015 ' (Decade 2005-2015..., 2005, p.16).

In fact, Stratfor predicted in 1995 that: 'Russia would regain lost parts of its empire by 2005' (Decade 1995-2005..., 1995, p.16). In other words we have to do with 3 different dates $(2005>2010>2015)$ for the same event. Let us recall here the case of Georgia (2008-2009) and Ukraine (since 2013; the Crimea and other territories in the East of Ukraine). 
In spite of such forecasts, Stratfor also predicted: 'a fundamental Russian crisis and prolonged fighting in various forms - including military conflict at times' - all that leading to Russia's disintegration. It never happened. In 2005 Stratfor predicted ('before the decade is out') that: '...pending leadership transitions in Egypt, Syria and Saudi Arabia will be major events' (Decade 20052015..., 2005, p.20,27, 29).

On one hand, as far as Saudi Arabia is concerned - nothing happened. On other hand let us recall here Arab Spring (2010-2012; Tunisia, Egypt, Libya, Syria, ISIS).

Stratfor expected the emergence of a Palestinian state - in the 'middle of the next decade (c. 2010) (Decade 2005-2015..., 2005, p.27). It never happened.

On the other hand, Stratfor predicted a collapse of the European Union as a political union - by 2015. Moreover, Stratfor expected: 'that one of its major countries - either France or Germany, in all likelihood will leave the Union' (Decade 2005-2015..., 2005, p.31). In fact, the European Union has to do with the Brexit problem.

Another prediction became a fact: 'The Central Europeans will run into a problem if a situation arises in the next decade in which an economic relationship with Europe and a military relationship with the United States are incompatible.

In 2005 Stratfor predicted that: 'Europe also could be torn asunder by an intensification of Islamist-related attacks...An increase in attacks would most certainly lead to extreme controls on immigration, mass deportations or even a pogrom against Muslims. Stratfor predicted mass-scale deportation of illegal and 'possibly even legal immigrants', as well as asylum camps - 'albeit not on European soil - by 2015' (Decade 2005-2015..., 2005, p.32-33). 'Extreme controls'? Mass-scale deportation of illegal and 'possibly even legal immigrants'? Nothing like that happened.

On the other hand, in Summer 2015, German Chancellor, A. Merkel, invited the Muslim immigrants to the European Union - without any consultations with other member states.

Stratfor predicted in 2005, that world attention will be dominated more by the Eurasian heartland and Western Pacific than by the Middle East (cf Iraq, Afghanistan, Syria, Iran) (Decade 2005-2015..., 2005, p.2). 
Stratfor enumerated various structural tensions in the Chinese economic system - leading to the economic and political weakening of China (the coast and the interior, the north and the south, the centre and the periphery). Instead, Chinese economy was on the rise.

Stratfor was unable to predict the case of Fukushima (2011; such a catastrophe was due to happen - sooner or later).

In the Decade Forecast: 2015-2025 Stratfor states: '...we have consistently forecast the enduring power of the United States. This is not a forecast rooted in patriotism or jingoism. It derives from our model (sic! - B.Z.Sz.) that continues to view the United States as the pre-eminent power'(Decade 2015-2025..., 2015, p.1).

The above quotation clearly reveals the 'methodology' of Stratfor.

In this Decade Forecast the problem of Brexit is missing (let us recall that Stratfor expected that France or Germany (not Britain) would leave the Union by 2015).

According to Stratfor: 'Germany will begin an extended economic decline that will lead to a domestic social and political crisis and that will reduce Germany's influence in Europe during the next 10 years'. In general, according to Stratfor, the main problem of the European Union 'is not the eurozone but the free trade zone'. Stratfor expects/predicts that the European Union 'may survive in some sense ('bilateral or limited multilateral relationships'). On the contrary, 'at the center of economic growth and increasing political influence will be Poland... we expect Poland to be the leader of an anti-Russian coalition. Poland will benefit from having a strategic partnership with the United States'. France and Germany will lose their Russian partner - Stratfor expects by 2025 'Moscow's authority to weaken substantially, leading - to the formal and informal fragmentation of Russia' (Decade 2015-2025..., 2015, p.3-5).

A. Konovalov regards the Decade Forcast: 2015-2025 as a 'scenario' - and 'pure fiction' (Konovalov, 2015 , p. 4).

In 2009, G. Friedman published a book: The Next 100 Years. A Forecast for the 21st Century (Friedman, 2009).

In fact, this book presents rather 'scenarios' than predictions/forecasts. The motto of this work is: 'the United States will remain the dominant global superpower in the 21 century'. 
G. Friedman prophesies (among other things) the following events/situations:

- political miscalculations of the European Union headed by Germany and France (the relations with Russia)

- demographic and economic problems in France and Germany before 2040 (economic collapse of France and Germany)

- in the 20-ies: chaos in Russia and China (cf the relationship between Russia and China; Shanghai Cooperation Organization - established in 1996 as 'Shanghai Five')

- the U.S. support for Poland - Poland becomes a local power (Szałek, 2011, p.198).

On the contrary, P.J. Buchanan published in 2011 the book: Suicide of a Superpower: Will America Survive to 2025? (Buchanan, 2011). Its content is definitely pessimistic, although Buchanan tries to indicate some solutions to this problem - such as, for example, 'economic patriotism', 'reduction of deficit' etc.

According to I. Morris, the following 40 years will be the most important period in history. The XXI century will resemble a race between a thorough/ deep transformation and a global disaster (Morris, 2010,p. 718).

\section{SOME FINAL REFLECTIONS CONCERNING THE 'FORECASTS' PUBLISHED BY STRATFOR/G. FRIEDMAN}

It is possible to indicate several methodological shortcomings with regard to the above-mentioned 'forecasts' published by Stratfor/G. Friedman.

For example:

- the influence of natural environment is practically neglected

- the 'forecasts' are based on a silent assumption that there will be no major natural catastrophes during the following 10-100 years (cf the problem of the caldera in Yellowstone)

- assumption that the United States will be the global hegemon (extrapolation)

I am not happy about the calibration/modification of 'forecasts' every 5 years (overlapping: 1995-2005, 2000-2010, 2005-2015, 2010-2020, 2015-2025; see (Szałek, 2015a)) 
tendentious selection of facts (in other words - disinformation, creation of false reality; eg concerning Europe; Israel and its lobbying organization AIPAC in the U.S.).

The discussed 'forecasts' are rather 'scenarios' built on the grounds of some long-term plans, wishful thinking and vivid imagination of decision makers in the U.S. (cf the predictions of 'leadership transitions' in Egypt, Syria between 2005 and 2015; 'Russia's deep systemic crisis' and 'an attempt by Washington to replace Putin with a more accommodating Russian president' (Decade 20052015..., 2005, p.19).

\section{SOME GENERAL REFLECTIONS}

One of many problems is the relationship between individual short-, middle - and long-term activities, based on various 'praxiological' suggestions, such, as for example, sociotechnics (suasion, manipulation, propaganda (inter alia: spin), coercion, brute force), political heuristics (eg: affiliation (party), ideology, appearance, polls, recommendations), political marketing, all sorts of 'art of war', psychotechnics, provocation, eristic, rhetoric, praxiology (Karwat, 2007, 2014; Nouzille 2015; Lau, Redlawsk, 2001; Sun Tzu, 1963; Sun Pin, 1995; Plebaniak, 2017; Volkoff, 1986; Rydlewski, 2009; Szałek, 2012; Green, 1998; Hadnagy, 2011; Keith, 1999; Koch, 2003; Kula, 2005; Lakhani, 2008; Pawełczyk, 2000; Roth, 2016; Tokarz, 2006) and political forecasting (for example: a prediction for the next 100 years gives an expected outcome of numerous aspirations, plots and intrigues of individuals not yet born).

Is it possible to establish the global resultant of milliards of individual aspirations by means of an extrapolation (say for the next 100 years - as promises G. Friedman) of the status quo? (Friedman, 1983).

What is certain in the anthroposphere and its surroundings?

Certain are human errors/mistakes (functional, structural), coincidence, 'black swans', emergentness, hinge factors, feed-backs (eg the U.S. - China), natural cycles (eg the solar cycle (around 11 years) (Cohen, Gooch, 1990; Durschmied, 1999; Taleb, 2007; Brunet, Guichard, 2011; Kisielewski, 2002; Kołodko, 2018; Weir, 1993). 
Some economists believe in economic cycles or waves (eg Kondratiev cycle (50-60 years), Juglar cycle ( $8-10$ years), Kitchin cycle (40 months)).

According to Stratfor: 'The united States has 50 year cycles that end with significant economic or social problems. One cycle began in 1932 with the election of Franklin Roosevelt and ended with the presidency of Jimmy Carter' (Decade 2015-2025..., 2015, p.11).

Stratfor believes in Russian phases: '...Russian phases usually last 25 to 45 years (such as the building of Soviet Russia as the second superpower from 1917 to 1961 and a period of stagnation from 1962 to 1991), the current phase might end as early as 2014 or 2015 (Decade 2005-2015..., 2005, p.17).

Some point at political/policy cycles (Howlett, Ramesh, 1995).

G. Brewer, dealing with stages heuristics, identifies 6 stages: 1) initiation, 2) estimation, 3) selection, 4) implementation, 5) evaluation, 6) termination (Brewer, 1974).

In certain countries (such as the United States, United Kingdom) one can observe 'the pendulum effect': two main parties rule by turns.

According to a theory proposed by R. Thom, there are 7 kinds of sudden changes ('catastrophes'). His theory is a qualitative attempt (not quantitative) at description and explanation of sudden changes (eg collapses) in, for example, human behaviour (Thom, 1972).

The so-called 'hinge factor' is compatible with that theory (Durschmied, 1999).

Some researchers are inclined to take seriously the so-called 'laws of history' (Koneczny, 1997, 1999) or the concepts of geopolitics (heartland, the Boulding principle (power vs. distance), etc.) (Szałek, 2015 a,b; Boulding, 1963; Białek, Oleksiuk, 2009; Brzeziński, 2013; Kisielewski, 2002; Klementewicz, 2013; Legucka, 2013; Flint, 2006; Jean, 2003; Żurawski, 2010).

Predictability depends (inter alia) on the extent and quality of relevant knowledge about mechanisms of this world (efficient mechanisms, faulty mechanisms (eg social engineering in the Soviet Union, North Korea, Cambodia (Pol Pot); the clash of ethics in the European Union), impossible mechanisms (like those painted by M. Escher), invisible mechanisms (cf the Group Bilderberg, freemasons, deep state/invisible government), illusory mechanisms (eg illusory alliances (Russia and China in the Shanghai Cooperation Organization)), mechanisms resembling 'ticking bombs' (eg outplacement of North-American 
crucial production to Japan, financial innovations, external debt of the U.S., Kashmir, Israel).

In general, the 'knowledge' of predictioners may be based on a mixture/ combination of true/genuine facts/information (complete and incomplete), misinformation (honest errors, mistakes), disinformation (deliberately fabricated false information (eg in the case of the 9/11 event, political lies (eg Russian lies about Katyń), intellectual lies (eg German lies about 'Polish death camps', British lies about Enigma) presented as facts, lack of genuine information, hushed up facts.

Predictions on the grounds of created reality (cf the North Korean reality vs. South Korean reality; the 'Overton window of political possibility', spin) are worthless (Sun Tzu, 1963; Pacepa, Rychlak, 2013; Volkoff, 1986).

Some situations are almost certain. For example: bad economic situation in Central Africa (Szałek, 2008), corruption in Ukraine and Russia, Muslim danger in the European Union.

On the contrary, I would not be so sure about the principle of Palmerston: 'Our interests are eternal and perpetual, and those interests it is our duty to follow' (Morris, 2010, p.538).

The complexity of the above problems explains the difficulty with 'engineering the future' and 'political forecasting.'

I. Morris illustrates this problem with a faulty forecast concerning the global warming (it was expected that in 2013 the polar summers would be free from ice) (Morris, 2010, p.707).

Another example is connected with the inability of top experts to forecast (in 2006-2007) the North-American > global financial crisis in 2008 and later (see also (Shirreff, 2016, Chancellor, 1990)).

Nevertheless, according to I. Morris, the epoch of the West will come to an end - at the latest - in 2103 (Morris, 2010, p.687). This opinion is very bold, especially if we take into consideration the huge time gap between 2010 and 2103 .

\section{BIBLIOGRAPHY:}

Białek, J., Oleksiuk, A. (2009). Gospodarka i geopolityka. Dokąd zmierza świat? Warszawa: Difin.

Boulding, K.E. (1963). Conflict and Defense, New York: Harper \& Brothers. 
Brewer, G. (1974). The policy sciences emerge: to nurture and structure a discipline. Policy Science 5 (3), pp.239-244.

Brunet, A., Guichard, J.-P. (2011). La visée hégémonique de la Chine, Paris: L'Harmattan.

Brzeziński, Z. (2013). Strategiczna wizja. Ameryka a kryzys globalnej potęgi. Kraków: Wydawnictwo Literackie.

Buchanan, P.J. (2011). Suicide of a Superpower: Will America Survive to 2025? Thomas Dunne Books.Polish edition: (2013). Samobójstwo supermocarstwa. Czy Ameryka przetrwa do roku 2025 ? Kobierzyce: Wyd. Wektory.

Chancellor, E. (1990). Devil Takes the Hindmost. A History of Financial Speculations, Polish ed.: (2001). Historia spekulacji finansowych. Warszawa: Muza S.A.

Cohen, E.A., Gooch, J. (1990). Military Misfortunes. The Anatomy of Failure in War. The Free Press, Polish ed.: (2010). Błędy i pomyłki w wojnach XX wieku. Warszawa: Bellona.

Decade Forecast: 1995-2005 (2005). Austin: Stratfor, Downloaded from: https:// www.stratfor.info/analysis/1995_2005_decade_forecast_g....

Decade Forecast: 2005-2015. (2005). Austin: Stratfor. Downloaded from: https:// worldview.stratfor.com/forecast/decade-forecast-2005-2015.

Decade Forecast: 2015-2025 (2015). Austin: Stratfor. Downloaded from: https:// worldview.stratfor.com/forecast/ decade-forecast-2015-2025.

De Mesquita, B. (2002). Predicting Politics. Columbus: Ohio State University Press.

De Mesquita, B. (2009). The Predictioneer's Game. Using the Logic of Brazen SelfInterest to See and Shape the Future, Random House.

De Mesquita, B. (2011). The Dictator's Handbook: Why Bad Behaviour is Almost Always Good Politics. Random House.

Dungaciu, D., Cristea, D., Dumitrescu, D.A., Zaharie, S.P. (2018). Stratfor vs. Reality (1995-2025). Dilemmas in Global Forecasting.Romanian Journal of Economic Forecasting, XXI (1), pp.167-178.

Durschmied, E. (1999). The Hinge Factor. How Chance and Stupidity Have Changed History.Polish ed.: (1999). Czynnik zwrotny w bitwach. Warszawa: Amber.

Flint, C. (2006). Introduction to Geopolitics, Abingdon: Routledge.

Franklin, D., Andrews, J. (eds.) (2012). Megachange: The World in 2050. London: Profile Books/The Economist.

Friedman, G. (2009). The Next 100 Years. A Forecast for the 21 ${ }^{\text {st }}$ Century. New YorkLondon-Toronto-Auckland: Doubleday.

Friedman, G. (2011). The Next Decade: What the World Will Look Like. New York: Doubleday.

Friedman, M. and R. (1983). Tyranny of the Status Quo. New York: Harcourt Brace Jovanovich. 
Friedman, Th. (2005) The World is Flat., Polish ed.: (2006). Świat jest płaski. Krótka historia XXI wieku. Poznań: Dom Wydawniczy Rebis.

Fukuyama, F. (2006) America at the Crossroads. Democracy, Power and the Neoconservative Legacy.Polish ed.: (2006). Ameryka na rozdrożu. Poznań: Dom Wydawniczy Rebis.

Gleiber, F.R., Rogerio, C.B. (2006). Uncertainty analysis in political forecasting. Decision Support Systems, 42, 1, p.25-35.

Green, R. (1998). The Concise 48 Laws of Power. London: Viking Penguin.

Hadnagy, Ch. (2011). Social Engineering: The Art of Human Hacking. Hoboken: Wiley.

Howlett, M., Ramesh, M. (1995). Studying public policy: Policy cycles and policy subsystems. Toronto-New York-Oxford: Oxford University Press.

Huntington, S. (1997). The Clash of Civilizations and the Remaking of World Order. New York: Touchstone.

Jean, C. (2003). Geopolityka. Wrocław: Ossolineum.

Karwat, M. (2007). Teoria prowokacji. Warszawa: Wydawnictwo Naukowe PWN.

Karwat, M. (2014). Podstawy socjotechniki dla politologów, polityków i nie tylko. Warszawa: Difin.

Keith, J. (1999). Mind Control, World Control. Kempton: Adventures Unlimited Press.

Kisielewski, T.A. (2002). Średnioterminowe perspektywy rozwoju sytuacji geostrategicznej. Rosja-Chiny-NATO. Toruń:Wyd. Adam Marszałek.

Klementewicz, T. (2013). Geopolityka trwałego rozwoju. Ewolucja cywilizacji i państwa w trakcie dziejotwórczych kryzysów. Warszawa: Dom Wydawniczy Elipsa.

Koch, E.R. (2013). Lizenz zum Töten. Die Mordkommandos der Geheimdienste. Berlin: Aufbau Verlag GmBH\&Co.KG.

Kołodko, G. (2018). Czy Chiny zbawia świat? Warszawa: Prószyński i S-ka.

Koneczny, F. (1997). Prawa dziejowe. Komorów: Wydawnictwo Antyk Marcin Dybowski.

Koneczny, F. (1999). O ład w historii, Wrocław: Nortom.

Konovalow, A. (2015). Critics on Stratfor Global Intelligence 'Decade Forecast'. Sankt Petersburg - Riga.

Kula, H.M. (2005). Propaganda wspótczesna. Toruń: Wydawnictwo Adam Marszałek.

Lakhani, D. (2008). Subliminal Persuasion: Influence and Marketing Secrets They Don't Want You to Know. New York: Wiley.

Lamont, Ch. (2015). Research Methods in International Relations, London: SAGE. Lau, R.R., Redlawsk, D.P. (2001). Advantages and disadvantages of cognotive heu- 
ristics in political decision making. American Journal of Political Science. 45, pp. 951-971.

Legucka, A. (2013). Geopolityczne uwarunkowania i konsekwencje konfliktów zbrojnych na obszarze poradzieckim. Warszawa: Difin.

Lorenzi, J.-H., Berrebi, M. (2015). Un monde des violences. L'économie mondiale 2016-2030. Paris: Groupe Eyrolles.

Lubowski ,A. (2013). Świat 2040. Czy Zachód musi przegrać?. Kraków: Wydawnictwo Znak.

Mauldin, J. (2005). Forecast: The Next Ten Years. Thoughts from the Frontline. April 16.

McRae, H. (1996). The World in 2020: Power, Culture and Prosperity. Boston: Harvard Business School Press.

Morris, I. (2010). Why the West Rules - For Now., Polish ed.: (2015). Dlaczego Zachód rządzi - na razie. Poznań: Zysk i S-ka.

Murray, D. (2017). The Strange Death of Europe. London: Bloomsbury Publishing. Nouzille, V. (2015). Les Tueurs de la Republique. Paris: Librairie Artheme Fayard.

Pacepa, I.M., Rychlak, R.J. (2013). Disinformation. WND Book Inc., Polish ed.: (2013). Dezinformacja. Gliwice: Helion.

Pawełczyk, P. (2000). Socjotechniczne aspekty gry politycznej. Poznań: Wydawnictwo Naukowe UAM.

Plebaniak, P. (2017). 36 forteli. Chińska sztuka podstępu, układania planów i skutecznego działania. Poznań: Zysk i Ska.

Randers, J. (2012). 2052: A Global Forecast for the Next Forty Years. Vermont: Chelsea Green Publishing.

Roth, J. (2016). Smolensk 2010 - Verschwörung die die Welt veränderte, Polish ed.: (2016). Smoleńsk 2010. Spisek który zmienit świat. Poznań: Zysk i S-ka.

Rydlewski, G. (2009). Rządzenie w świecie megazmian. Warszawa: Dom Wydawniczy: Elipsa.

Shirreff, R. (2016). 2017: The War with Russia, Polish ed.: (2016). 2017 Wojna $z$ Rosję. Poznań: Dom Wydawniczy Rebis.

Slonim Ori (2018). National intelligence: A tool for political forecasting and the forecasting of rare events. Technological Forecasting and Social Change. 128, March 2018, pp.245-251.

Sun Tzu (1963). The Art of War. Oxford: At the Clarendon Press.

Sun Pin.(1995), Military Methods of the Art of War. New York: Barnes \& Noble Books.

Szałek, B.Zb. (2008). Kilka refleksji na temat sprawności rzadzenia i gospodarowania w Afryce, w: Pomoc Afryce - rzeczywistość czy fikcja? A.M. Bytyń, J. Bylińska (eds.). Szczecin: Uniwersytet Szczeciński. 
Szałek, B.Zb. (2015a) Kilka prakseologicznych uwag na temat globalnych wyzwań w kontekście Polski, in: Teoria i praktyka polityki. Perspektywa szczecińskich politologów, red. R. Podgórzańska, J. Ruszkowski, Szczecin: WNWHUS Minerwa, pp.97-114.

Szałek, B.Zb. (2015b). Kilka prakseologicznych refleksji na temat geopolityki i myśli politycznej. Od geopolityki do topologii politycznej, in: Myśl polityczna w XX i XXI wieku. Vol. 1. Ed. A. Wojtaszak. Szczecin: WNWHUS Minerwa, p.127149.

Szałek, B.Zb. (2015c). Geopolitics, Political Topology and Hybrid Warfare, Reality of Politics. 6, p. 86-97.

Taleb, N.N. (2007). The Black Swan: The Impact of the Highly Improbable. New York: Random House.

Thom, T. (1972/1975). Stabilité structurelle et morphogenèse (Structural stability and morphogenesis. An outline of a general theory of models), Reading, Massachusetts: Benjamin W.A.

Tokarz, M. (2006). Argumentacja. Perswazja. Manipulacja. Gdańsk: Gdańskie Wydawnictwo Psychologiczne.

Trejderowski, T. (2009). Socjotechnika. Podstawy manupulacji w praktyce. Warszawa: Eneteia. Wydawnictwo Psychologii i Kultury.

Volkoff, V. (1986). La désinformation arme de guerre. Paris: Julliard.

Weir, W. (1993). Fatal Victories. History's Most Tragic Military Triumphs and the High Cost of Victory. New York: Pegasus Books.

Żurawski vel Grajewski, P. (2010). Geopolityka - siła - wola. Rzeczypospolitej zmagania z losem. Kraków: Ośrodek Myśli Politycznej. 